\title{
The use of Some Aliphatic Halorgano antimony Compounds as combustion Retarding agents of Unsaturated Polyester and Epoxy Resins
}

\author{
Areej Kamal A.AL-Dabagh* \\ Received 2, February, 2009 \\ Accepted 6, November, 2009
}

\begin{abstract}
:
Four antimony compounds were used in this inves as additives to retard combustion of unsaturated polyester and epoxy resins, namely:

1. Tetraethyl ammonium tribromoethylantimonates (additive I).

2. Tetraethyl ammonium chlorodibromoethylantimonates (additive II).

3. Tetraethyl ammonium trichloroethylantimonates (additive III).

4. Tetraethyl ammonium bromodichloroethylantimonates (additive IV).

The effects of these additives on flammability of unsaturated polyester and epoxy resins have been studied by using sheets of the resins with weight percentages of $(0.5,1.0,1.5,2.0,2.5 \& 3.0 \%)$ of the additives in dimensions of $(150 \times 150 \times 3) \mathrm{mm}$. Three standard test methods were used to measure the flame retardation which are:

(ASTM:D -2863), (ASTM:D-635)and (ASTM:D-3014).

The results obtained from these tests indicated that, additive I has a high efficiency as flame retardant causing, self - extinguishing (S.E.) at the percentage of $(2.0 \%)$ for unsaturated polyester resin and the percentage $(2.5 \%)$ for epoxy resin.

Self - extinguishing (S.E.) of additives II and IV were at the percentage of (2.5\%) for unsaturated polyester resin and $(3.0 \%)$ in the case of epoxy resin. Additive III showed low effect on flammability in both resins.
\end{abstract}

Key words: Flame retardant, additives, Aliphatic Halorgano antimony Compounds, unsaturated polyester and epoxy resins.

\section{Introduction:}

The history of all polymer materials were traced by the success of their applications in replacing traditional materials like wood, leather and metals. The rapid expansion of combustion gave motives to many researchers to use many additives to retard flammability of the polymers [1].

Flame retardation is essentially an interruption of the burning process [2]. There are two distinct types of flame retardants must be recognized:

a - Reactive flame retardants are compounds usually containing heteroelements which can also be chemically incorporated in smaller proportions, usually during the polymerization process.

b - Additives flame retardants are incorporated into polymers by physically mixing with the polymer, normally after complete polymerization [3, 4].

Halogen compounds [5] and antimony complex compounds [6] were widely used as commercial flame retardants. Rhys and Cleaver [7], studied the combustion of polyester laminates containing

*Chemistry Department / College of Science for women / Baghdad University 
pentabromotoluene, they observed that the optimum atomic ratio of $(\mathrm{Sb}: \mathrm{Br})$ for flame retardancy is $(1: 3)$.

In (1993) Ugal [8], prepared some organo halogenated compounds ( mixed types haloantimonates) in which antimony was the central element, such as $\mathrm{Et}_{4} \mathrm{~N}\left[\mathrm{PhSbCl}_{2} \mathrm{Br}\right]$. In (1999) Ahmed [9] , prepared some aliphatic and aromatic mixed haloantimonates compounds and used them as flame retardants with polyethylene and polystyrene such as $\mathrm{Et}_{4} \mathrm{~N}\left[\mathrm{EtSbCl}_{2} \mathrm{Br}\right.$. In (2005) Al -Baiati [10], prepared the compound $\mathrm{Et}_{4} \mathrm{~N}\left[\mathrm{PhPCl}_{2} \mathrm{Br}\right]$ and used it as flame retardant with unsaturated polyester and epoxy resins. These compounds contain in their structure atoms such as bromine , chlorine, phosphorous, nitrogen , antimony and phenyl ring , the ratio between halogen atoms and antimony or phosphorous atoms is (3:1), this ratio represents the ideal ratio for high efficiency in flame retardant ability and non- burning properties for the polymeric materials $[9,10]$.

\section{Materials and Methods:}

\section{A. Polymers:}

1. Unsaturated polyester resin, hardener type (MEKP), imported from Industrial Chemical and Resins Co. Ltd, Kingdom of Sudia Arabia.

2. Epoxy resin, type (CY223), hardener type (HY956), imported from Ciba - Geigy Co.

B. Flame - retardants materials :

1. Additive I: Tetraethylammonium tribromoethyl antimonates $\mathrm{Et}_{4} \mathrm{~N}\left[(\mathrm{Et}) \mathrm{SbBr}_{3}\right]$.

2.AdditiveII:Tetraethylammoniumchlo rodibromoethylantimonates

$\mathrm{Et}_{4} \mathrm{~N}\left[(\mathrm{Et}) \mathrm{SbBr}_{2} \mathrm{Cl}\right]$.

3. Additive III: Tetraethylammonium trichloroethyl antimonates $\mathrm{Et}_{4} \mathrm{~N}\left[(\mathrm{Et}) \mathrm{SbCl}_{3}\right]$.
4. Additive IV: Tetraethylammonium bromodichloroethyl antimonates $\mathrm{Et}_{4} \mathrm{~N}\left[\left(\mathrm{C}_{2} \mathrm{H}_{5}\right) \mathrm{SbCl}_{2} \mathrm{Br}\right]$.

All of them were prepared as reported in literature[11].

\section{Tests:}

1. ASTM:

D-2863: The measurements of limiting oxygen Index (LOI) is widely used for measuring flammability of polymers [12].

2. ASTM: D-635: This deals with the measurement of rate of burning (R.B), Average time of burning (ATB), Non burning (N.B), Self- extinguishing (S.E) and Average extent of burning (AEB) for self Supporting plastic in a horizontal position [13].

3. ASTM: D-3014: This method was used to measure the maximum flame height $(\mathrm{H})$, and the ratio of loss of weight of polymeric materials [14].

\section{Preparation of Samples:}

Samples were prepared tow in dimensions of (150X150X3) mm, three sheets of each unsaturated polyester and epoxy resins were prepared having the percentage weight $(0.5,1.0,1.5$, $2.0,2.5 \& 3.0 \%)$ of the additives. These sheets cut as samples according to ASTM standard used in this work.

\section{Results and Discussion:}

1. Measurement of limiting oxygen index (LOI) according to ASTM: D 2863:

The limiting oxygen index (LOI) for unsaturated polyester resin without additives is (20.4) [15] and for epoxy resin without additives is (19.7) [16]. , (Tables - 1 and 2) and (Figs.-1 and 2) indicated that , oxygen concentration required to support a candle - like in unsaturated polyester and epoxy resins samples increased with increasing the weight percentage of additives .The efficiency of additives under study were in the following order : I $>$ II $>$ IV $>$ III 
2. Measurement of rate of burning (R.B) according to ASTM: D-635:

Results obtained from these tests showed that the rate of burning (R.B) of the resins with additives are inversely proportional with the percentage weight of additives, as indicated in (Tables -3 and 4) and (Fig.- 3 and 4) which show the flame speed curves of flame retardation for the resins.

3. Measurement of flame height $(\mathrm{H})$ according to ASTM: D-3014:

Figs.-5 and 6 showed that, the maximum flame height $(\mathrm{H})$ was decreased with increasing the percentage weight of additives (inversely proportional), as indicated in Tables -5 and 6 respectively. The results obtained from this test indicated that, the same efficiency of additives are in a good agreement with the measurements of LOI and rate of burning respectively.

The action of these additives was due to the formation of chare as aresult of removing the hydrogen atoms from the polymer chains with the liberation of the hydrochloric acid HCL which acts in the gas phase. The combustion products like; free radicals $\left({ }^{\circ} \mathrm{Cl},{ }^{\circ} \mathrm{OH}\right)$, chare,...etc., will form a layer to prevent burning and prevent oxygen to help contineous burning of polymers.

Results obtained from these tests showed that, the bromine atom was more effective from chlorine atoms to retard combustion for both resins.

Table 1: Limiting Oxygen Index (LOI) for unsaturated polyester resin with additives

\begin{tabular}{|c|c|c|c|c|c|c|c|}
\hline $\begin{array}{r}\text { Additives } \\
\text { Additives }\end{array}$ & Non & 0.5 & 1.0 & 1.5 & 2.0 & 2.5 & 3.0 \\
\hline I & 20.4 & 21.50 & 21.95 & 22.47 & 23.0 & 23.45 & 23.77 \\
\hline II & 20.4 & 21.31 & 21.80 & 22.30 & 22.85 & 23.34 & 23.52 \\
\hline III & 20.4 & 20.85 & 21.32 & 21.71 & 22.28 & 22.85 & 23.11 \\
\hline IV & 20.4 & 21.02 & 21.55 & 22.07 & 22.63 & 23.19 & 23.43 \\
\hline
\end{tabular}

Table 2: Limiting Oxygen Index (LOI) for epoxy resin with additives.

\begin{tabular}{|c|c|c|c|c|c|c|c|}
\hline $\begin{array}{c}\text { Additives\% } \\
\text { Additives }\end{array}$ & Non & 0.5 & 1.0 & 1.5 & 2.0 & 2.5 & 3.0 \\
\hline I & 19.7 & 20.73 & 21.35 & 21.98 & 22.48 & 22.89 & 23.3 \\
II & 19.7 & 20.54 & 21.11 & 21.77 & 22.30 & 22.75 & 23.08 \\
III & 19.7 & 20.23 & 20.82 & 21.41 & 21.88 & 22.36 & 22.84 \\
IV & 19.7 & 20.35 & 20.94 & 21.49 & 22.01 & 22.47 & 22.93 \\
\hline
\end{tabular}

Table 3: Rate of burning (RB) for unsaturated polyester resin with additives.

\begin{tabular}{|c|c|c|c|c|c|c|c|c|}
\hline \multirow{4}{*}{ TEST } & Non & 0.5 & 1.0 & 1.5 & 2.0 & 2.5 & 3.0 & additives \\
\hline \multirow{4}{*}{ AEB (cm) } & 10 & 10 & 9.8 & 9.2 & 8.5 & 7.1 & 6.4 & I \\
\cline { 2 - 10 } & 10 & 10 & 10 & 9.7 & 9.0 & 8.3 & 7.5 & II \\
\cline { 2 - 9 } & 10 & 10 & 10 & 10 & 9.6 & 9.1 & 8.4 & III \\
\cline { 2 - 9 } & 10 & 10 & 10 & 1.0 & 9.4 & 8.7 & 8.0 & IV \\
\hline \multirow{4}{*}{ ATB(min.) } & 6.92 & 8.47 & 8.67 & 8.52 & 8.50 & 7.97 & 8.31 & I \\
\cline { 2 - 9 } & 6.92 & 8.19 & 8.54 & 8.66 & 8.57 & 8.93 & 9.14 & II \\
\cline { 2 - 9 } & 6.92 & 7.75 & 8.06 & 8.40 & 8.42 & 8.45 & 8.75 & III \\
\cline { 2 - 9 } & 6.92 & 7.93 & 8.33 & 8.69 & 8.6 & 8.96 & 8.98 & IV \\
\hline \multirow{4}{*}{ R.B } & 1.44 & 1.18 & 1.13 & 1.08 & 1.0 & 0.89 & 0.77 & I \\
\cline { 2 - 9 } (Cm/min.) & 1.44 & 1.22 & 1.17 & 1.12 & 1.05 & 0.93 & 0.82 & II \\
\cline { 2 - 9 } & 1.44 & 1.29 & 1.24 & 1.19 & 1.14 & 1.07 & 0.96 & III \\
\cline { 2 - 9 } & 1.44 & 1.26 & 1.20 & 1.15 & 1.09 & 0.97 & 0.89 & IV \\
\hline \multirow{4}{*}{ S.E. } & - & - & - & - & yes & yes & yes & I \\
\cline { 2 - 9 } & - & - & - & - & - & yes & yes & II \\
\cline { 2 - 9 } & - & - & - & - & - & - & yes & III \\
\cline { 2 - 9 } & - & - & - & - & - & yes & yes & IV \\
\hline \multirow{4}{*}{ N.B } & - & - & - & - & - & - & - & I \\
\cline { 2 - 9 } & - & - & - & - & - & - & - & II \\
\cline { 2 - 9 } & - & - & - & - & - & - & - & III \\
\cline { 2 - 8 } & - & - & - & - & - & - & - & IV \\
\hline
\end{tabular}

Table 4: Rate of burning ( $R B$ ) for epoxy resin with additives.

\begin{tabular}{|c|c|c|c|c|c|c|c|c|}
\hline additives\% & Non & 0.5 & 1.0 & 1.5 & 2.0 & 2.5 & 3.0 & additives \\
\hline \multirow{4}{*}{$\mathrm{AEB}(\mathrm{cm})$} & 10 & 10 & 10 & 10 & 9.5 & 8.3 & 7.2 & I \\
\hline & 10 & 10 & 10 & 10 & 10 & 8.7 & 4.8 & II \\
\hline & 10 & 10 & 10 & 10 & 10 & 9.7 & 9.1 & III \\
\hline & 10 & 10 & 10 & 10 & 10 & 9.4 & 8.8 & IV \\
\hline \multirow{4}{*}{$\mathrm{ATB}(\min )}$. & 5.12 & 8.0 & 4.8 & 9.0 & 8.8 & 8.7 & 8.3 & I \\
\hline & 5.12 & 7.8 & 8.1 & 8.5 & 8.9 & 8.4 & 9.2 & II \\
\hline & 5.12 & 7.4 & 7.8 & 8.1 & 8.4 & 8.8 & 9.0 & III \\
\hline & 5.12 & 7.6 & 8.0 & 8.3 & 8.6 & 8.9 & 9.1 & IV \\
\hline \multirow{4}{*}{$\begin{array}{c}\text { R.B } \\
(\mathrm{Cm} / \mathrm{min} .)\end{array}$} & 1.95 & 1.25 & 1.19 & 1.11 & 1.07 & 0.95 & 0.86 & I \\
\hline & 1.95 & 1.28 & 1.22 & 1.17 & 1.12 & 1.03 & 0.91 & II \\
\hline & 1.95 & 1.34 & 1.27 & 1.23 & 1.18 & 1.09 & 1.01 & III \\
\hline & 1.95 & 1.31 & 1.24 & 1.20 & 1.15 & 1.05 & 0.96 & IV \\
\hline \multirow{4}{*}{ S.E. } & - & - & - & - & - & yes & yes & I \\
\hline & - & - & - & - & - & - & yes & II \\
\hline & - & - & - & - & - & - & - & III \\
\hline & - & - & - & - & - & - & yes & IV \\
\hline \multirow{3}{*}{ N.B } & - & - & - & - & - & - & - & I \\
\hline & - & - & - & - & - & - & - & II \\
\hline & - & - & - & $=$ & $=$ & - & - & IV \\
\hline
\end{tabular}


Table 5: Flame height $(\mathrm{H})(\mathrm{cm})$ for unsaturated polyester resin with additives.

NOTE:

\begin{tabular}{|c|c|c|c|c|c|c|c|c|}
\hline \multirow{4}{*}{$\begin{array}{c}\text { W1 } \\
\text { (gm) }\end{array}$} & Non & 0.5 & 1.0 & 1.5 & 2.0 & 2.5 & 3.0 & additives \\
\hline & 5.63 & 6.07 & 6.11 & 6.15 & 6.19 & 6.23 & 6.27 & I \\
\cline { 2 - 9 } & 5.63 & 6.04 & 6.09 & 6.12 & 6.16 & 6.20 & 6.24 & II \\
\cline { 2 - 9 } & 5.63 & 5.69 & 5.73 & 5.76 & 5.79 & 5.83 & 5.86 & III \\
\cline { 2 - 9 } & 5.63 & 5.82 & 5.86 & 5.89 & 5.93 & 5.97 & 6.01 & IV \\
\hline \multirow{4}{*}{$\begin{array}{c}\text { TeST } \\
(\mathrm{gm})\end{array}$} & 2.57 & 2.14 & 2.17 & 2.19 & 2.22 & 2.25 & 2.28 & I \\
\cline { 2 - 9 } & 2.57 & 2.09 & 2.11 & 2.14 & 2.17 & 2.20 & 2.23 & II \\
\cline { 2 - 9 } & 2.57 & 1.94 & 1.97 & 2.00 & 2.03 & 2.06 & 2.09 & III \\
\cline { 2 - 9 } & 2.57 & 1.98 & 2.01 & 2.04 & 2.07 & 2.10 & 2.14 & IV \\
\hline \multirow{4}{*}{$\begin{array}{c}\text { PWR } \\
(\%)\end{array}$} & 54.35 & 64.74 & 64.48 & 64.39 & 64.13 & 63.88 & 63.63 & I \\
\cline { 2 - 9 } & 54.35 & 65.39 & 65.35 & 65.03 & 64.77 & 64.51 & 64.26 & II \\
\cline { 2 - 9 } & 54.35 & 65.90 & 65.61 & 65.27 & 64.93 & 64.66 & 64.33 & III \\
\cline { 2 - 9 } & 54.35 & 65.97 & 65.69 & 65.36 & 65.09 & 64.82 & 64.39 & IV \\
\hline \multirow{4}{*}{$\begin{array}{c}\text { H } \\
(\mathrm{cm})\end{array}$} & 14.0 & 9.0 & 8.5 & 8.0 & 7.0 & 6.0 & 4.5 & I \\
\cline { 2 - 9 } & 14.0 & 9.5 & 9.0 & 8.5 & 7.5 & 6.5 & 5.0 & II \\
\cline { 2 - 8 } & 14.0 & 11.5 & 11.0 & 10.5 & 10.0 & 9.5 & 9.0 & III \\
\cline { 2 - 8 } & 14.0 & 11.0 & 10.5 & 10.0 & 9.5 & 9.0 & 8.5 & IV \\
\hline
\end{tabular}

W1: weight of sample before burning (gm)

W2: weight loss after burning (gm).

PWR: The percentage of Weight Ratio (\%) .

Table 6: Flame height $(\mathrm{H})(\mathrm{cm})$ for epoxy resin with additives .

\begin{tabular}{|c|c|c|c|c|c|c|c|c|}
\hline additives \% & Non & 0.5 & 1.0 & 1.5 & 2.0 & 2.5 & 3.0 & additives \\
\hline \multirow{4}{*}{$\begin{array}{c}\text { W1 } \\
\text { (gm) }\end{array}$} & 4.52 & 5.02 & 5.05 & 5.08 & 5.11 & 5.14 & 5.18 & I \\
\hline & 4.52 & 5.00 & 5.03 & 5.06 & 5.09 & 5.12 & 5.16 & II \\
\hline & 4.52 & 4.61 & 4.64 & 4.67 & 4.70 & 4.73 & 4.76 & III \\
\hline & 4.52 & 4.68 & 4.71 & 4.74 & 4.77 & 4.80 & 4.83 & IV \\
\hline \multirow{4}{*}{$\begin{array}{l}\mathrm{W} 2 \\
(\mathrm{gm})\end{array}$} & 1.43 & 1.04 & 1.06 & 1.08 & 1.10 & 1.12 & 1.14 & I \\
\hline & 1.43 & 1.07 & 1.09 & 1.11 & 1.13 & 1.15 & 1.17 & II \\
\hline & 1.43 & 1.09 & 1.11 & 1.14 & 1.17 & 1.20 & 1.23 & III \\
\hline & 1.43 & 1.10 & 1.12 & 1.15 & 1.18 & 1.21 & 1.25 & IV \\
\hline \multirow{4}{*}{$\begin{array}{c}\text { PWR } \\
(\%)\end{array}$} & 68.36 & 79.28 & 79.01 & 78.74 & 78.47 & 78.21 & 77.99 & I \\
\hline & 68.36 & 78.60 & 78.33 & 78.06 & 77.79 & 77.53 & 77.32 & II \\
\hline & 68.36 & 76.35 & 76.07 & 75.58 & 75.10 & 74.63 & 74.15 & III \\
\hline & 68.36 & 76.49 & 76.22 & 75.73 & 75.26 & 74.79 & 74.12 & IV \\
\hline \multirow{4}{*}{$\begin{array}{c}\mathrm{H} \\
(\mathrm{cm})\end{array}$} & 12.0 & 8.0 & 7.5 & 6.5 & 6.0 & 5.5 & 5.0 & I \\
\hline & 12.0 & 8.5 & 8.0 & 7.5 & 7.0 & 6.5 & 6.0 & II \\
\hline & 12.0 & 11.0 & 10.5 & 10.0 & 9.5 & 9.0 & 8.3 & III \\
\hline & 12.0 & 10.5 & 10.0 & 9.5 & 9.0 & 8.5 & 8.0 & IV \\
\hline
\end{tabular}

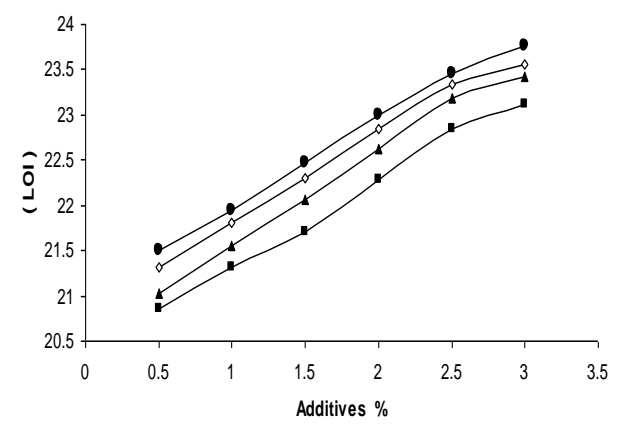

Fig. (1): (LOI) for unsaturated polyester resin with additives.

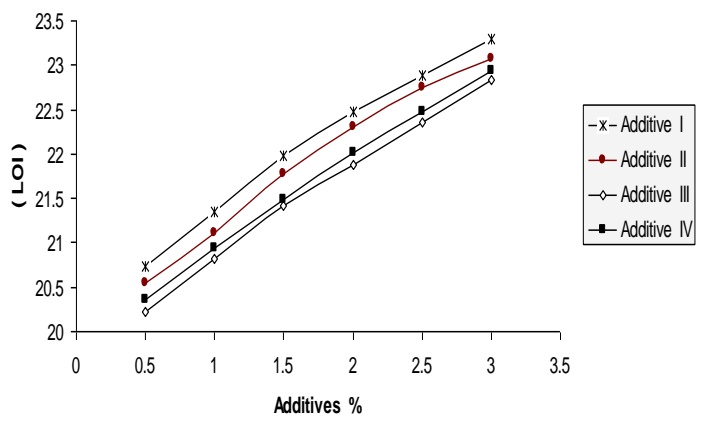

Fig. (2): (LOI) for epoxy resin with additives. 


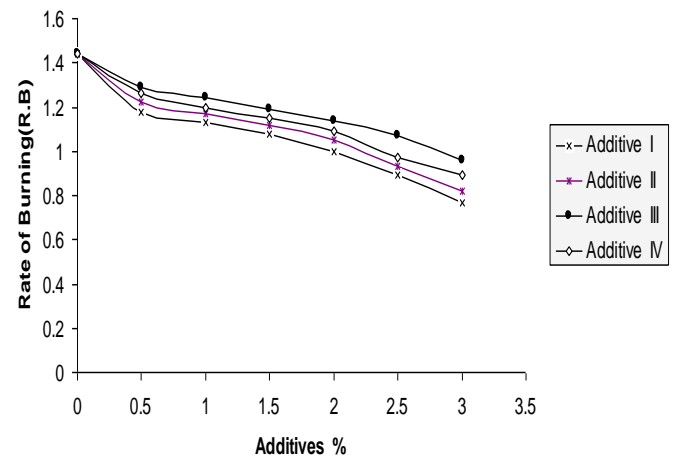

Fig. (3): Rate of burning (R.B.) for unsaturated polyester resin with additives.

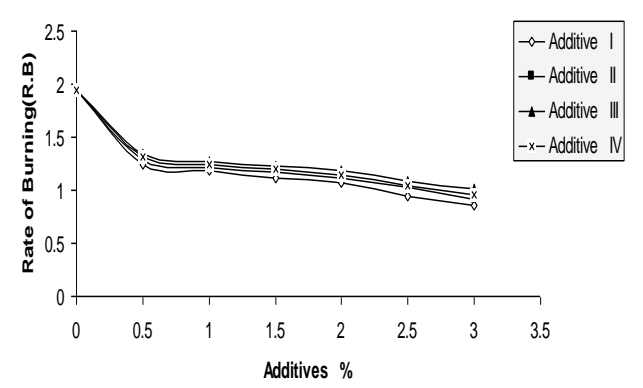

Fig.(4) : Rate of burning (R.B.) for epoxy resin with additives .

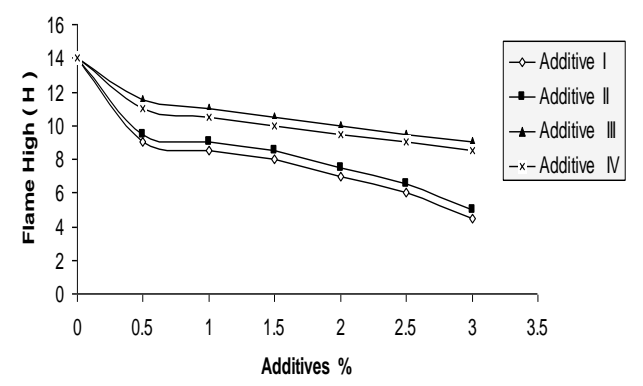

Fig. (5): Flam height (H) for unsaturated polyester resin with additives

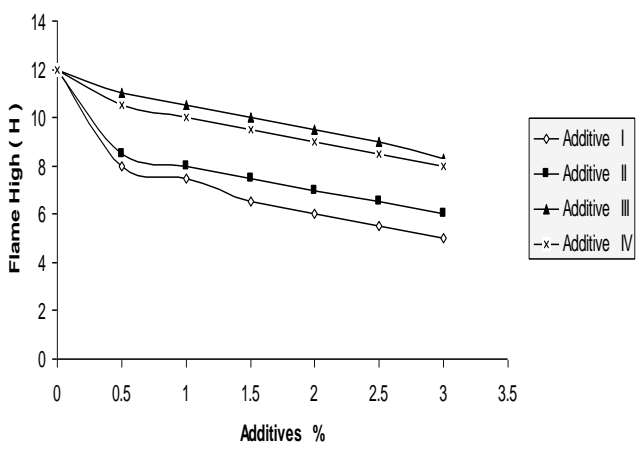

Fig • (6): Flam height (H) for epoxy resin with additives.

\section{References:}

1.Mark, H.F., Gay lord, N.G. and Bikales N.M. 1971, Encyclopedia of Polymer Science and Technology, London .7. 598.

2.Albright, J.A. and Kmiec, C.J. 1978, Mechanisms of flame retardants, J. Appl .Polymer .Sci. 22. 2451.

3.Hirschler, M.M. 1975, Flame retardant mechanisms, city university press, London, pp 110.

4.Atlas, S.M. and Pearce, E.M. 1975," Flame-retardant polymeric materials ", plenum press, New York, pp 20.

5.Kuryla, W.C. and papa,A.J. 1973, "Flame retardancy of polymeric materials ", Marcel Dekker, New York. 5 .156.

6.Cullis, C.F. and Hirschler, M.M. 1981, the combustion of organic polymers, oxford university press, oxford pp. 82.

7.Rhys J. and Cleaver M.; cited by, Kuryla W.C. and Papa A.J. 1975, "Flame retardancy of polymeric materials", Marcel Dekker, New York. 3. 301.

8.Ugal, J.R., Jha, N.K, and Pankaj, S. 1993, Mixed halophenyl antimonates (III), Ind.J.Chem .320 .71.

9.Ahmed A.F. 1999 " Thesis", University of Mustansyria , College of Scince.

10. Al- Baiati, M.N, 2005,"Studying the effect of using some inorganic additives for flame retardancy and 
increase of five resistance of unsaturated polyester resin and epoxy resin", University of Baghdad, College of Science For Women.

11. Al-Dabagh, A. K. 2006,"Synthesis of some haloorgano antimony compounds and studying the biological activity on some mocroorganisms", University of Baghdad, College of Science for women .

12. American society for testing materials .Annual Book of ASTM standards. Textiles, Fibers; ASTM: philadephia, 1986., Vol.08.01.

13. American society for testing materials. Annual Book of ASTM standard. Textiles, Fibers; ASTM: philadephia 1981. Part - 35.
14. American society for testing materials. Annual Book of ASTM standard. Textiles, Fibers; ASTM: philadephia 1976. Part - 35.

15. Al- Baiati, M.N. 2007,"J. of College of Basic Education ","The combined action of polyammoniumphosphate and chlorinated rubber as flameretardants for unsaturated polyester resin ". 51.75 .

16. Al- Baiati, M.N. 2006,"J. of College of Basic Education", the synergistic effect of Diammoniumphosphate and chlorinated paraffin as flame retardants for epoxy resin" . 46. 9 .

\section{دراسة تأثير بعض مركبات الانتيمون العضوية الهالوجينية الاليفاتية في تثبيط

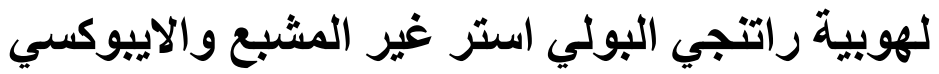

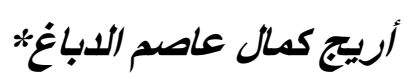

$$
\begin{aligned}
& \text { *قسم الكيمياء /كلية العلوم للبنات / جامعة بغداد } \\
& \text { استخدمت في هذا البحث أربعة معقدات بوصفها مضافات لتنبيط لهوبية راتنجي البولي استر غير المشبـع و }
\end{aligned}
$$

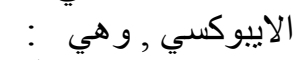

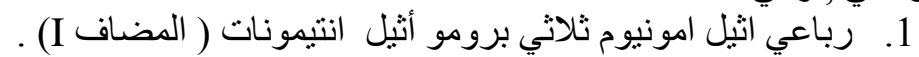

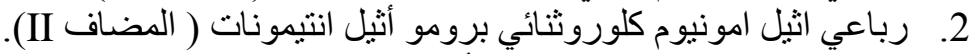

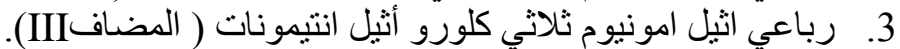

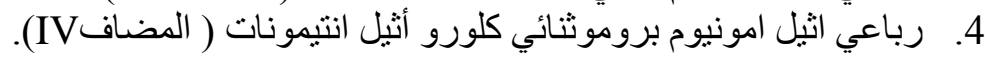

لقد تمت دراسة تأثثر هذه المضافات في تتبيط لهوبية راتتجي البولي استر غير المشبع والاييوكسي. وذلك

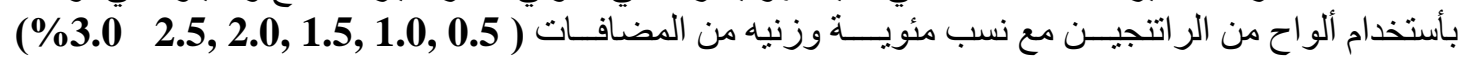
وبقياسات (150x150x3) ملم. استخدمت ثلاث طر ائق قياسية لقياس تثبيط اللهوبية هي (AST) (ASTM:D-3014 ) . (ASTM:D-635), (ASTM:D-2863)

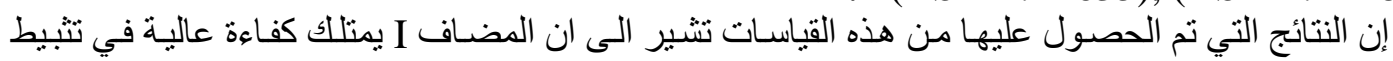

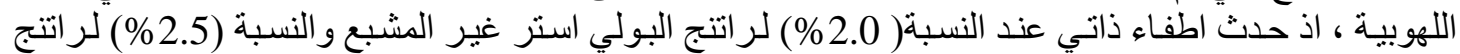

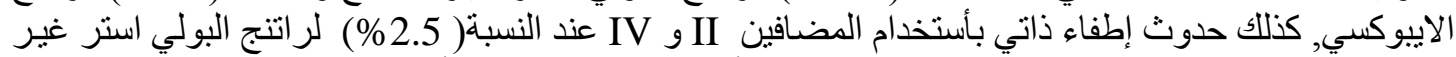

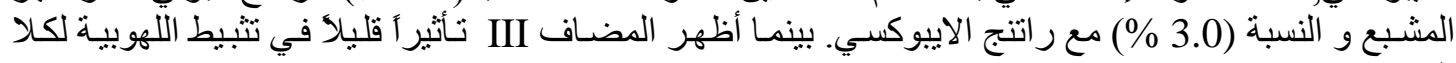

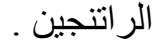

